\title{
Level Pemahaman Konsep Fluida Mahasiswa Calon Guru Fisika dalam Project Based Laboratory (PJB-Lab)
}

\author{
Juli Firmansyah ${ }^{1 *}$, Andi Suhandi ${ }^{2}$, Agus Setiawan $^{3}$, dan Anna Permanasari ${ }^{4}$ \\ 1,2,3,4 Program Studi Doktoral Pendidikan IPA, Sekolah Pascasarjana, Universitas Pendidikan Indonesia, \\ JI. Dr. Setiabudi No. 229, Bandung 40154, Indonesia \\ 1 Program Studi Pendidikan Fisika, Universitas Serambi Mekkah, \\ Jl. Tgk. Imum Lueng Bata, Batoh, Banda Aceh \\ *E-mail: juli.firman@upi.edu
}

\begin{abstract}
Abstrak
Pemahaman Konsep Fisika menjadi perhatian setiap proses pembelajaran dan praktikum fisika. Pengembangan berbagai konsep praktikum fisika dalam model inquiry Lab atau Project Based Lab berkontribusi pada Level Pemahaman Konsep Mahasiswa. Penelitian ini dilakukan untuk mengetahui level pemahaman konsep mahasiswa calon guru fisika pada konsep fluida melalui praktikum fisika berbasis proyek (PJB-Lab). Metode yang digunakan adalah pre eksperimental dengan desain one group pretest and posttest. Subjek penelitian ini adalah 22 mahasiswa calon guru fisika pada salah satu Universitas di Kota Banda Aceh, Aceh. Instrumen tes yang digunakan adalah tes level pemahaman konsep dalam bentuk uraian bertingkat yang terdiri dari kemampuan penjelasan konsep dari sebuah kasus yang diberikan (P), kemampuan menentukan hukum fisika yang menjelaskan kasus tersebut $(\mathrm{Q})$, kemampuan memberikan contoh kasus tambahan tentang hukum terkait $(\mathrm{R})$ dan mendefinisikan hukum tersebut (S). Hasil penelitian menunjukkan bahwa mahasiswa calon guru fisika mencapai pemahaman konsep fluida pada level memahami secara utuh (MSU) setelah mengikuti praktikum fisika berbasis proyek. Oleh karena itu dapat disimpulkan bahwa tingkat pemahaman konsep fisika efektif meningkat mencapai memahami secara utuh melalui praktikum fisika berbasis proyek.
\end{abstract}

Kata kunci: Level Pemahaman Konsep, Konsep Fluida, Praktikum Fisika Berbasis Proyek

\begin{abstract}
Understanding Physics Concepts is a concern for every learning process and physics practicum. The development of various physics practicum concepts in the Inquiry Lab or Project Based Lab models contributes to the Students' Concept Understanding Level. This study was conducted to determine the level of conceptual understanding of students on the concept of fluid through project-based laboratory. The method used is pre-experimental with one group pretest and posttest design. The subjects of this study were 22 prospective physics teacher students at one of the universities in Banda Aceh City. The test instrument used is a level test of concept understanding in the form of a stratified description consisting of the ability to explain the concept $(P)$, the ability to determine the laws of physics ( $Q$ ), ability to provide additional case examples of related laws $(R)$ and define those laws (S). The results showed that students achieved an understanding of fluid concepts at the level of complete understanding (CU) after participating in a project-based laboratory. Therefore, it can be concluded that the level of understanding of physics concepts effectively increases to achieve complete understanding through project-based laboratory.
\end{abstract}

Keywords: Level of Understanding, Fluid Concepts, Project-Based Laboratory.

\section{PENDAHULUAN}

Tuntutan kompetensi abad 21 tentang keterampilan tidak hanya menekankan penguasaan kemampuan dan keterampilan, namun juga memberikan porsi yang sesuai untuk tingkat pemahaman konsep dan perubahan sikap (Ontario, 2016; Binkley dkk, 2012). Salah satu upaya untuk memfasilitasi meningkatkan level atau tingkat pemahaman konsep adalah melalui aktivitas praktikum. 
Dalam praktikum, sebagai bagian utuh dari perkuliahan kelas, aktivitas laboratorium abad 21 tentu saja membekali keterampilan 4C (Soland, Hamilton, \& Stecher, 2013) namun tidak menutup kesempatan pembekalan pemahaman konsep yang utuh serta perubahan sikap terhadap praktikum fisika (Putri dkk, 2019).

Konsep fisika adalah pondasi dimana keterampilan dan sikap disandarkan. Keterampilan abad 21 diantaranya keterampilan berpikir kritis dan kreatif, memiliki prasyarat penguasaan konten secara utuh dan pemahaman konsep tanpa miskonsepsi (Firmansyah \& Suhandi, 2021). Dengan kata lain, keterampilan berpikir kritis dan kreatif akan muncul jika pemahaman konsepnya utuh dan komprehensif (Malik \& Ubaidillah, 2020).

Temuan dan fakta berdasarkan studi dokumentasi dan observasi (Firmansyah dkk, 2019) dalam pelaksanaan praktikum, model praktikum sangat menentukan bagaimana aktivitas praktikum tersebut membekali penguasaan konsep yang utuh, melatihkan keterampilan dan membentuk sikap terhadap eksperimen fisika. Model praktikum verifikasi yang digunakan untuk konsep fisika dasar pada program studi pendidikan fisika pada kampus LPTK di Aceh, belum berhasil membekali pemahaman konsep yang utuh untuk mahasiswa calon guru fisika. Model praktikum inquiri ditemukan cukup efektif dalam membekali keterampilan proses sains mahasiswa calon guru fisika (Saputra dkk, 2019), namun praktikum berbasis inquiri belum dominan membantu penguasaan konsep yang komprehensif (Maulidah \& Prima, 2018). Oleh sebab itu, perlu diperkenalkan sebuah model baru yang dapat membekali keterampilan, membentuk sikap dan sekaligus membekali penguasaan konsep yang baik (Diani dkk, 2018). Praktikum pada abad 21 tidak hanya dipandang sebagai aktivitas pembuktian dan konfirmasi konsep fisika yang telah dipelajari pada pertemuan di kelas (Bajpai, 2013), namun aktivitas laboratorium harus dapat membekali konsep yang utuh, keterampilan berpikir dan mencapai tingkat pemahaman konsep secara utuh.

Tingkat pemahaman konsep (Saglam-
Arslan \& Devecioglu, 2010) dapat ditentukan dari jawaban soal tingkat pemahaman konsep dengan kriteria (Yusal dkk, 2021) Tidak Menjawab (TMJ), Tidak Memahami (TMH), Memahami Secara Keliru (MSK), Memahami Sebagian (MSB), dan Memahami Secara Utuh (MSU). Salah satu alternatif untuk meningkatkan tingkat pemahaman konsep fluida adalah praktikum berbasis proyek. Praktikum fisika berbasis proyek merupakan praktikum yang menekankan pada penyelesaian proyek sebagai produk praktikum untuk menerapkan konsep yang telah dikonfirmasi dan ditemukan dalam aktivitas praktikum. Praktikum fisika berbasis proyek memiliki dua aktifitas utama, yaitu penguatan konsep melalui tahapan eksplorasi, kemudian hasil eksplorasi konsep diterapkan untuk menyelesaikan proyek pada tahapan selanjutnya yang meliputi aktivitas merencanakan, menyelesaikan, menguji dan mengevaluasi produk. Dengan dua tahapan ini, tingkat pemahaman konsep fisika dapat dicapai secara utuh dan komprehensif.

Berdasarkan paparan tersebut, peneliti mengkaji tingkat pemahaman konsep mahasiswa calon guru fisika melalui praktikum fisika berbasis proyek.

\section{METODE/EKSPERIMEN}

Metode yang digunakan dalam penelitian adalah pre-eksperimental dengan desain one group pretest-posttest. Penelitian ini melibatkan 22 mahasiswa sebagai subjek yang berasal dari salah satu Perguruan Tinggi Lembaga Pendidikan Tenaga Pendidikan (LPTK) di Kota Banda Aceh. Tahapan penelitian diawali dengan pemberian pretest terhadap subjek penelitian. Selanjutnya subjek penelitian mengikuti praktikum fisika berbasis proyek dengan target produk adalah kapal selam yang merupakan penerapan konsep mengapung, melayang dan tenggelam dan produk drone/helicopter yang merupakan penerapan prinsip Bernoulli. Setelah praktikum fisika berbasis proyek selesai, subjek diberikan posttest untuk mengukur tingkat pemahaman konsep fluida. Desain dan alur penelitian dijelaskan dalam gambar 1 di bawah. 


Pretest $\quad$ Posttest

Gambar 1. Desain Penelitian

Instrumen test tingkat pemahaman konsep fluida dirancang dengan empat tingkat pemahaman yang memerlukan kemampuan penjelasan konsep dari sebuah kasus yang diberikan (tingkat $\mathrm{P}$ ), kemampuan menentukan hukum fisika yang menjelaskan kasus tersebut (tingkat $Q$ ), kemampuan memberikan contoh kasus tambahan tentang hukum terkait (tingkat R) dan mendefinisikan hukum tersebut (tingkat S). Contoh Instrumen bertingkat PQRS diperlihatkan pada gambar 2. Instrumen tes tingkat pemahaman konsep fluida disusun sebanyak delapan butir soal bertingkat PQRS terkait hukum Archimedes dan PQRS terkait prinsip Bernoulli.

\section{PQRS 1}

P. Bagaimana anda menjelaskan sebuah kapal selam akan menyelam pada saat sedang mengapung, dan akan mengapung pada saat sedang tenggelam?

Q. Konsep/hukum fisika apakah yang dapat menjelaskan fenomena tersebut?

R. Sebutkan contoh lain penerapan konsep fisika tersebut dalam kehidupan seharihari?

S. Berdasarkan jawaban pada butir soal sebelumnya, dengan menggunakan katakata anda sendiri definisikan konsep tersebut serta tulis persamaannya?

Gambar 2. Contoh Instrumen Tingkat Pemahaman Konsep

Pengukuran level pemahaman konsep fluida pada hukum Archimedes dan Prinsip Bernoulli, dilakukan dengan kriteria jawaban dan pemberian skor sesuai level pemahaman dan kriteria jawaban mahasiswa (SaglamArslan \& Devecioglu, 2010) sebagaimana dijelaskan pada tabel 1. Data dianalisis dengan metode analisis data statistik deskriptif untuk mengetahui gambaran perbedaan tingkat atau level pemahaman konsep sebelum dan sesudah praktikum fisika berbasis proyek.

Tabel 1. Kriteria Jawaban Level Pemahaman

\begin{tabular}{|c|c|c|}
\hline Skor & Level Pemahaman & Kriteria Jawaban \\
\hline 0 & $\begin{array}{l}\text { Tidak Menjawab } \\
\text { (TMJ) }\end{array}$ & $\begin{array}{lr}\text { Tidak } & \text { Mengisi } \\
\text { jawaban atau } \\
\text { menjawab saya } \\
\text { tidak mengerti. }\end{array}$ \\
\hline 1 & $\begin{array}{l}\text { Tidak Memahami } \\
(\mathrm{TMH})\end{array}$ & $\begin{array}{l}\text { Jawaban salah } \\
\text { dan tidak relevan } \\
\text { dengan } \\
\text { pertanyaan }\end{array}$ \\
\hline 2 & $\begin{array}{l}\text { Memahami Secara } \\
\text { Keliru (MSK) }\end{array}$ & $\begin{array}{l}\text { Jawaban kurang } \\
\text { tepat karena } \\
\text { memberikan } \\
\text { konsep yang } \\
\text { keliru atau konsep } \\
\text { yang terbalik. }\end{array}$ \\
\hline 3 & $\begin{array}{l}\text { Memahami } \\
\text { sebagian (MSB) }\end{array}$ & $\begin{array}{l}\text { Jawaban benar } \\
\text { menyebutkan } \\
\text { konsep, tetapi } \\
\text { masih ada keliru } \\
\text { dalam penjelasan } \\
\text { konsep }\end{array}$ \\
\hline 4 & $\begin{array}{l}\text { Memahami secara } \\
\text { utuh (MSU) }\end{array}$ & $\begin{array}{l}\text { Jawaban benar } \\
\text { mencakup semua } \\
\text { aspek secara } \\
\text { jelas, fokus dan } \\
\text { akurat }\end{array}$ \\
\hline
\end{tabular}

\section{HASIL DAN PEMBAHASAN}

\section{HASIL}

Pengumpulan data dilakukan dalam dua kali perlakuan praktikum yaitu sebelum dan sesudah praktikum fisika dasar berbasis proyek sehingga menghasilkan produk kapal selam dan drone/helikopter. Dalam penyelesaian produk proyek tersebut, mahasiswa harus mampu menerapkan konsep fisika secara benar dan bebas dari miskonsepsi. Hasil pengumpulan data dari pretest dan posttest disajikan pada tabel 2 di bawah. Berdasarkan data hasil penelitian, tingkat pemahaman konsep fluida mahasiswa calon guru fisika berada antara level memahami secara keliru (MSK) hingga memahami secara utuh (MSU). Temuan ini dapat dikonfirmasi berdasarkan hasil penelitian pada tabel 2 yang menunjukkan persentase mahasiswa calon guru fisika dapat mencapai level memahami secara utuh (MSU) pada tahap posttest. 
Tabel 2. Tingkat pemahaman konsep fluida

\begin{tabular}{cccc}
\hline \multirow{2}{*}{ Konsep } & Level & $\begin{array}{c}\text { Pretest } \\
(\%)\end{array}$ & $\begin{array}{c}\text { Posttest } \\
(\%)\end{array}$ \\
\hline \multirow{3}{*}{ Archimedes } & MSK & 45 & 0 \\
\cline { 2 - 4 } & MSB & 55 & 7 \\
\cline { 2 - 4 } Bernoulli & MSU & 0 & 93 \\
\cline { 2 - 4 } & MSK & 27 & 0 \\
\cline { 2 - 4 } & MSB & 73 & 9 \\
\cline { 2 - 4 } & MSU & 0 & 91 \\
\hline
\end{tabular}

Pada konsep Hukum Archimedes, hasil pretest menunjukkan masih terdapat mahasiswa calon guru fisika yang memahami secara keliru/salah paham (45\%) dan secara parsial/sebagian (55\%) bagaimana kapal selam bekerja menerapkan hukum Archimedes. Penyelesaian produk kapal selam diawali dengan penjelasan tentang prinsip kerja kapal selam dan kaitannya dalam konsep fisika. Selanjutnya mahasiswa digiring untuk menjawab pertanyaan pengarah proyek sehingga dapat mengidentifikasi konsepkonsep fisika yang bekerja pada kapal selam. Tahap selanjutnya adalah mahasiswa melakukan pengembangan konsep melalui aktivitas eksplorasi konsep. Akhirnya dengan alat dan bahan yang disediakan secara terbatas, menantang mahasiswa untuk mulai merancang kapal selam dan menyelesaikan produk kapal selam sebagaimana gambar 3 . Mahasiswa menggunakan paralon, syringe, dinamo, sumber tegangan dan beban penyeimbang.

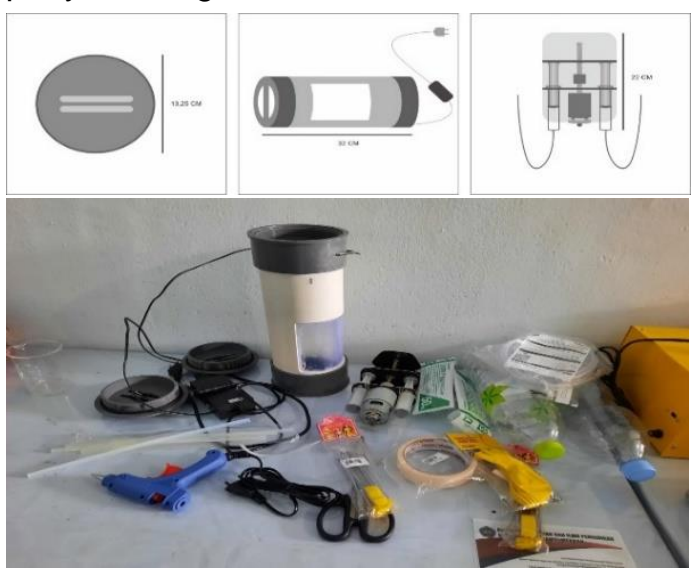

Gambar 3. Produk Kapal Selam

Setelah menyelesaikan produk kapal selam, mahasiswa mengikuti postetst, hasilnya menunjukkan bahwa mahasiswa dapat mencapai $93 \%$ pada tingkat memahami secara utuh dan sisanya $7 \%$ mahasiswa masih tetap pada level memahami secara sebagian. Gambar 4 menjelaskan perubahan tingkat pemahaman konsep sebelum dan sesudah praktikum fisika berbasis proyek kapal selam.

Produk kapal selam yang diselesaikan oleh mahasiswa telah diuji coba dan berhasil menerapkan konsep mengapung, melayang dan tenggelam. Kapal selam dapat mengapung, melayang dan tenggelam disebabkan dinamo yang bergerak mengakibatkan syringe maju dan mundur sehingga dapat mengontrol air dalam tabung syringe keluar dan masuk ke dalam lambung kapal selam.

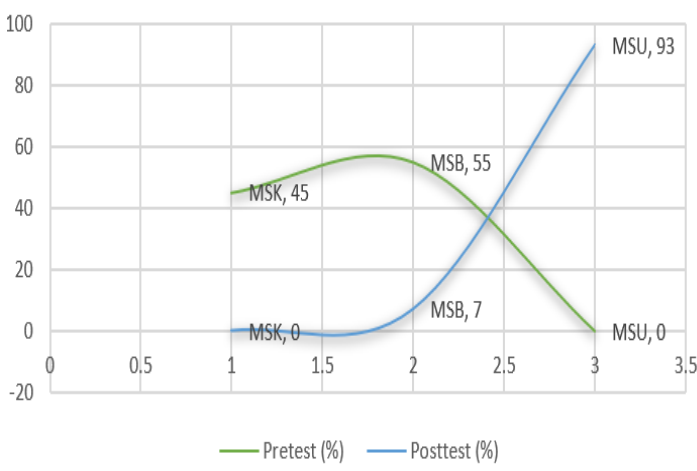

Gambar 4. Level/Tingkat Pemahaman Konsep Archimedes

Pada konsep Prinsip Bernoulli, awalnya semua mahasiswa tidak memahami secara utuh bagaimana prinsip Bernoulli bekerja untuk menerbangkan drone, berdasarkan data yang ditemukan, pada saat pretest mahasiswa calon guru fisika yang memahami secara keliru sebesar $27 \%$ dan memahami secara parsial/sebagian sebesar $73 \%$.

Produk Drone/Helikopter yang diselesaikan oleh mahasiswa terbatas pada rancangan propeller atau baling-baling dengan menerapkan prinsip Bernoulli yang menjelaskan hubungan antara kecepatan aliran udara dan tekanan udara di sekitar propeller. Tahapan praktikum dimulai dengan memahami prinsip kerja drone dan mengidentifikasi konsep fisika yang terlibat. Selanjutnya mahasiswa melakukan aktivitas eksplorasi konsep untuk menemukan hubungan besaran dan konsep fisika dalam prinsip kerja Drone. Propeler dalam produk drone yang disiapkan oleh mahasiswa harus dirancang untuk dapat 
membentuk sudut datang yang sesuai untuk dapat mengatur kecepatan aliran udara dan tekanan udara di bawah dan di atas propeller. Propeler dibuat dari bahan botol plastik yang dibentuk menyerupai bentuk propeller dengan sudut tertentu kemudian dipasangkan pada tutup botol yang telah dihubungkan ke dinamo. Propeler digerakkan oleh dinamo dan tenaga baterai, ukuran dan bentuk propeler disesuaikan sehingga dapat mengangkat drone terbang vertikal. Gambar 5 memperlihatkan produk drone dan propeler yang telah disiapkan oleh mahasiswa.

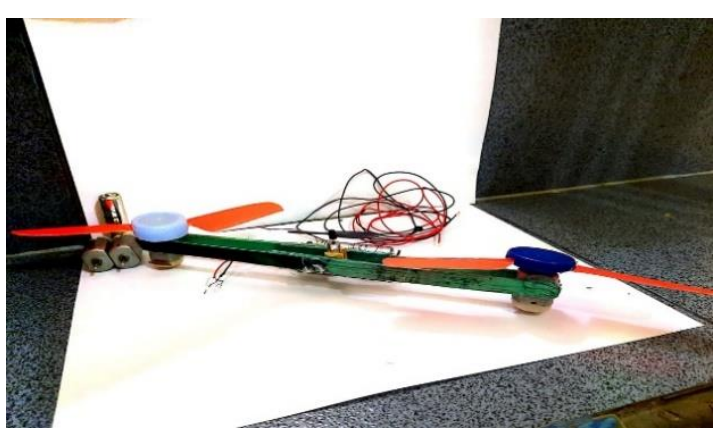

Gambar 5. Drone dan Propeler

Hasil uji coba produk menunjukkan drone berhasil melayang secara vertikal, mahasiswa berhasil menerapkan prinsip Bernoulli pada propeler drone secara benar. Setelah menyelesaikan produk drone, mahasiswa mengikuti post-test level pemahaman konsep Bernoulli, hasil posttest seperti pada gambar 6 menunjukkan persentase mahasiswa calon guru fisika, yang memahami secara utuh mencapai $91 \%$ dan hanya $9 \%$ masih tetap pada level memahami secara sebagian.

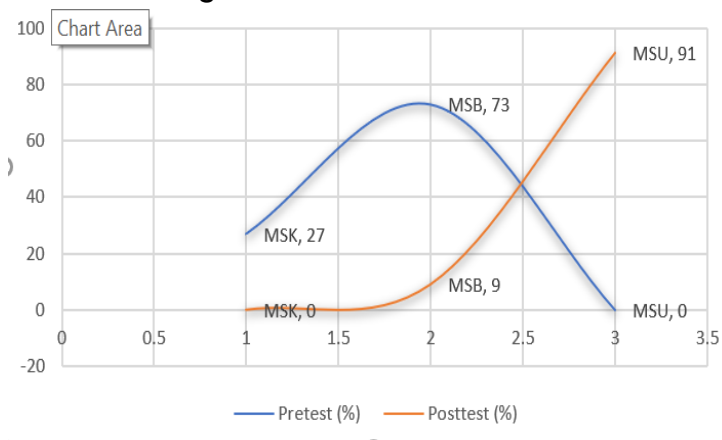

Gambar 6. Level/Tingkat Pemahaman Konsep Bernoulli.

\section{PEMBAHASAN}

Berdasarkan hasil penelitian yang telah disajikan, diketahui bahwa pemahaman awal mahasiswa calon guru fisika terhadap konsep hukum Archimedes, pada level memahami secara keliru atau salah paham (45\%) dan memahami sebagian (55\%). Hal ini mengindikasikan bahwa mahasiswa sudah memiliki pengetahuan awal sebelum mengikuti praktikum PJB-Lab. Walaupun masih terdapat kesalahpahaman dan pemahaman yang parsial, pengetahuan awal ini menjadi modal dasar dalam melakukan eksplorasi dan menyelesaikan proyek (Aramayo dkk, 2013) sehingga mencapai level pemahaman yang utuh (MSU).

Diantara permasalahan yang ditemukan dalam kesalahpahaman konsep dan pemahaman yang parsial yaitu pada penjelasan keadaan benda pada saat mengapung dan akan tenggelam (Yadav, 2014). Sebagian besar mahasiswa meyakini bahwa sebuah benda yang terapung hanya akan tenggelam jika massa jenis benda berubah menjadi lebih kecil dari pada massa jenis fluida, padahal selisih antara gaya berat benda dan gaya apung yang bekerja pada benda juga menjadi penyebab sebuah benda akan tenggelam (Kiray, Aktan, Kaynar, Kilinc, \& Gorkemli, 2015) sebagaimana dijelaskan pada tabel 3.

Tabel 3. MSB dalam Hukum Archimedes

\begin{tabular}{cl}
\hline MSB & \multicolumn{1}{c}{ MSU } \\
\hline$\rho_{\text {benda }}>\rho_{\text {air }}$ & $\rho_{\text {benda }}>\rho_{\text {air }}$ \\
$=$ tenggelam & $=$ tenggelam \\
& $w_{\text {benda }}>F_{a}$ \\
& $=$ tenggelam \\
\hline
\end{tabular}

Berdasarkan penjelasan tabel di atas, dipahami bahwa tidak semua kondisi dapat dijelaskan dengan perbedaan massa jenis yang menyebabkan keadaan benda (mengapung, melayang dan tenggelam) dalam fluida, tetapi terdapat kondisi tertentu tanpa mengubah massa jenis benda, benda yang sama dapat tenggelam jika pengaruh gaya apung terhadap benda diperkecil. Contohnya sebuah piring kaca, dapat mengapung jika diletakkan secara horizontal di atas permukaan air, namun piring yang sama, jika di letakkan vertikal ( $F_{a}$ diperkecil, $\rho$ tetap) di atas permukaan air, maka piring tersebut akan tenggelam.

Setelah melakukan aktivitas PJB-Lab 
melalui eksplorasi konsep dan penyelesaian proyek kapal selam, kesalahpahaman konsep atau memahami konsep secara keliru (MSK) mahasiswa calon guru fisika dapat direduksi hingga $45 \%$ dan memahami konsep secara sebagian (MSB) dikurangi hingga 48\%. Sedangkan peningkatan pemahaman konsep secara utuh, meningkat secara signifikan mencapai $93 \%$ setelah posttest.

Level pemahaman awal konsep fluida pada topik prinsip Bernoulli, juga berada pada level memahami secara keliru sebesar $27 \%$ dan memahami sebagian sebesar $73 \%$. Angka ini mengindikasikan bahwa kesalahpahaman terhadap prinsip Bernoulli lebih sering terjadi dibandingkan hukum Archimedes.

Permasalahan kekeliruan pemahaman (MSK) pada prinsip Bernoulli sering terjadi pada saat menjelaskan kecepatan aliran udara dan tekanan udara di atas propeler dan di bawah propeler (Profile, 2016). Sebagian mahasiswa awalnya meyakini bahwa perubahan kecepatan partikel udara yang menghasilkan perbedaan tekanan sehingga menciptakan gaya angkat (Bastianello, 2013).

Peningkatan level pemahaman konsep fluida secara utuh (MSU) mencapai 93\% terjadi setelah mahasiswa calon guru fisika terlibat aktif dalam mengeksplorasi prinsip Bernoulli dan menerapkannya dalam prinsip kerja propeler atau bilah ketika drone dapat naik ke udara (Almensoury dkk, 2021). Mahasiswa sudah dapat mengidentifikasi prinsip Bernoulli secara benar pada propeller drone dan dapat menjelaskan bagaimana perubahan kecepatan aliran udara dan perubahan tekanan udara pada propeller dipengaruhi oleh bentuk propeler yang melengkung. llustrasi gambar 7 dibawah ini menjelaskan bagaimana hubungan antara kecepatan aliran udara dengan tekanan udara pada saat propeller berputar.

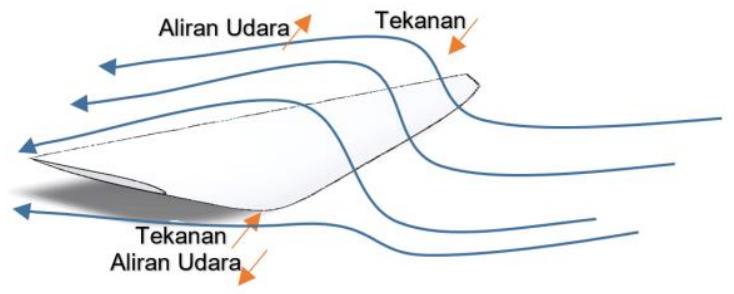

Gambar 7. Perubahan Aliran dan Tekanan Udara
Pemahaman konsep mahasiswa terkait prinsip Bernoulli menjadi utuh melalui aktivitas eksplorasi konsep dengan meniupkan bagian permukaan selembar kertas yang melengkung, sehingga dapat menghasilkan gaya angkat, Namun, fakta sebagaimana ditunjukkan pada gambar 8, menemukan bahwa tidak ada gaya angkat yang dihasilkan jika meniup selembar kertas yang digantung vertikal. Temuan ini kemudian menemukan hubungan perubahan kecepatan aliran dan tekanan udara dengan kelengkungan. Kesimpulan eksplorasi konsep ini kemudian diterapkan oleh mahasiswa dalam produk drone dengan propeller yang memiliki kelengkungan sehingga menghasilkan gaya angkat.

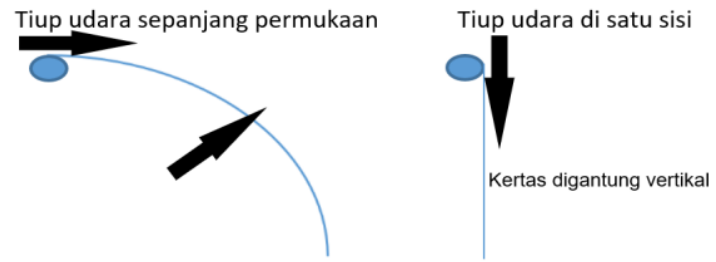

Gambar 8. Eksplorasi Prinsip Bernoulli

Perbandingan perubahan level pemahaman konsep fluida mahasiswa setelah mengikuti PJB-Lab dijelaskan pada gambar 9. 


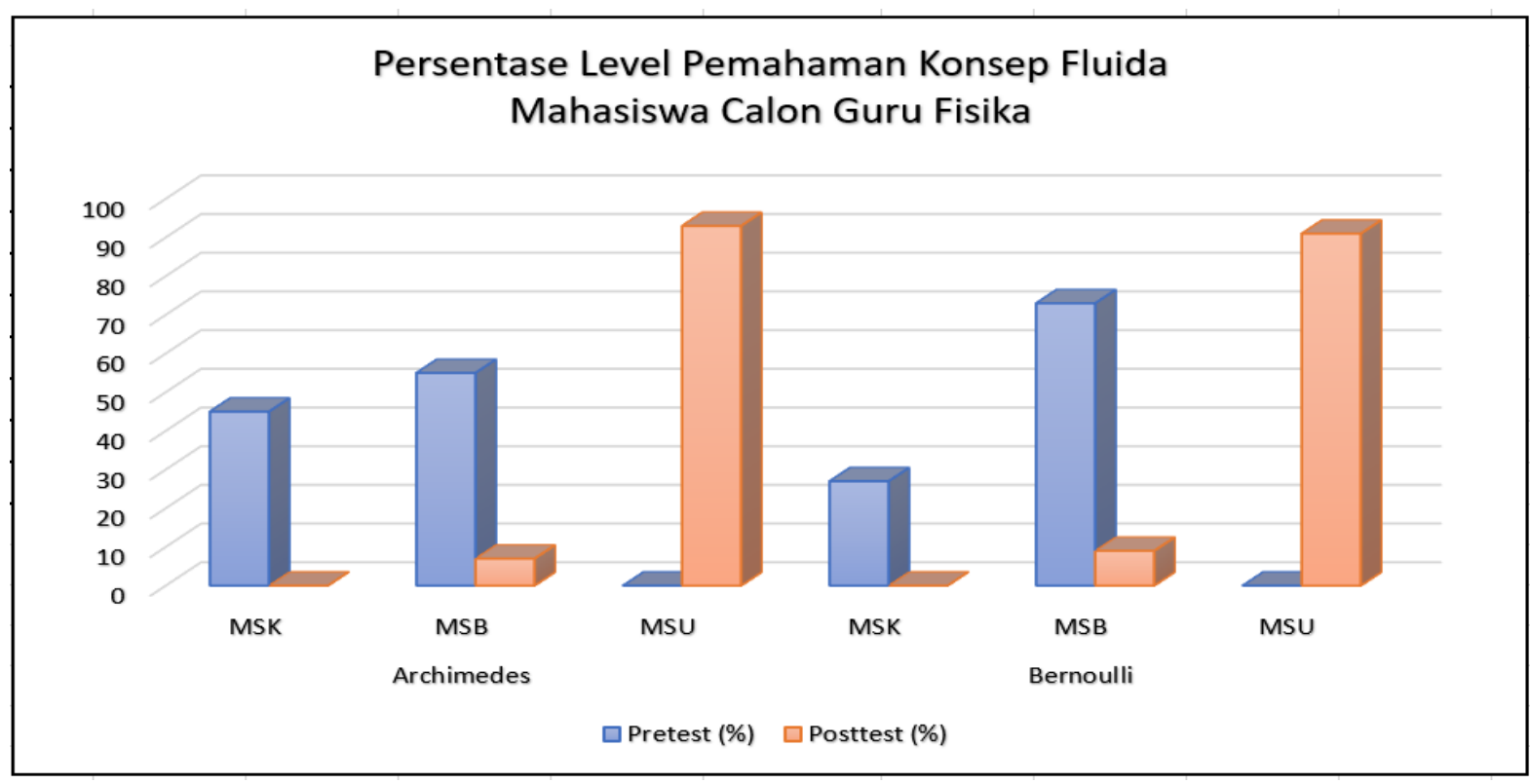

Gambar 9. Grafik perbandingan Level Pemahaman Konsep Fluida

\section{PENUTUP}

Berdasarkan hasil penelitian dan pembahasan, dapat disimpulkan bahwa kesalahpahaman atau memahami konsep secara keliru dapat dikurangi dan direduksi dengan menerapkan praktikum berbasis proyek. Selain itu, konsep fisika dapat dipahami secara utuh ketika mahasiswa terlibat aktif dalam aktivitas eksplorasi konsep dan penyelesaian proyek degan menerapkan konsep fisika pada proyek sebagai produk praktikum.

Oleh karena itu, penerapan Praktikum Fisika berbasis proyek (PJB-Lab) dapat dipertimbangkan sebagai alternatif peningkatan level pemahaman konsep fluida mahasiswa calon guru fisika.

\section{UCAPAN TERIMAKASIH}

Ucapan terima kasih kami sampaikan kepada LPTK di kota Banda Aceh yang telah memberikan kesempatan untuk mengumpulkan data untuk keperluan penelitian ini.

\section{REFERENSI}

Almensoury, M. F., Alkhafaji, D., \& Al-Turaihi, R. S. (2021). Aerodynamic study for the flow through cascade blades of gas turbine with vibration effect: a review. IOP Conference Series: Materials Science and Engineering, 1090(1), 012131. https://doi.org/10.1088/1757899x/1090/1/012131

Bajpai, M. (2013). Developing concepts in physics through virtual lab experiment: An effectiveness study. International Journal of Educational Technology, 3(1), 43-50.

Bastianello, F. (2013). Lift generation: Some misconceptions and truths about Lift. Young Scientists Journal, 6(13), 12. https://doi.org/10.4103/09746102.107612

Diani, R., Latifah, S., Anggraeni, Y. M., \& Fujiani, D. (2018). Physics Learning Based on Virtual Laboratory to Remediate Misconception in Fluid Material. Tadris: Jurnal Keguruan Dan IImu Tarbiyah, 3(2), 167.

https://doi.org/10.24042/tadris.v3i2.3321

Firmansyah, J., \& Suhandi, A. (2021). Critical thinking skills and science process skills in physics practicum. Journal of Physics: Conference Series, 1806(1). https://doi.org/10.1088/17426596/1806/1/012047

Kiray, S. A., Aktan, F., Kaynar, H., Kilinc, S., \& Gorkemli, T. (2015). A descriptive study of pre-service science teachers' misconceptions about sinking-floating. Asia-Pacific Forum on Science Learning and Teaching, 16(2), 1-28. 
Malik, A., \& Ubaidillah, M. (2020). Students critical-creative thinking skill: A multivariate analysis of experiments and gender. International Journal of Cognitive Research in Science, Engineering and Education, 8(Special Issue 1), 49-58. https://doi.org/10.23947/2334-84962020-8-SI-49-58

Marilyn Binkley, Ola Erstad, Joan Herman, Senta Raizen, M. R., \& May Miller-Ricci, and M. R. (2012). Defining Twenty-First Century Skills. In Assessment and teaching of 21 st century skills (Vol. 9789400723, pp. 1-345). https://doi.org/10.1007/978-94-007-23245

Maulidah, S. S., \& Prima, E. C. (2018). Using Physics Education Technology as Virtual Laboratory in Learning Waves and Sounds. Journal of Science Learning, 1(3), 116. https://doi.org/10.17509/jsl.v1i3.11797

Ontario Public Service. (2016). 21 Century Competencies. Towards Def Ining 21s $t$ Century Competenc les for Ontario, 1-66. Retrieved from http://www.edugains.ca/resources21CL/2 1stCenturyLearning/21CL_21stCenturyC ompetencies.pdf

Profile, S. E. E. (2016). Misinterpretations of Bernoulli's Law. (June).

Putri, D. H., Risdianto, E., Sutarno, S., \& Hamdani, D. (2019). The development of cooperative problem solving physics laboratory model on simple pendulum concept. Journal of Physics: Conference Series, https://doi.org/10.1088/1742 6596/1157/3/032005

Saglam-Arslan, A., \& Devecioglu, Y. (2010). Student teachers' levels of understanding and model of understanding about Newton's laws of motion. Asia-Pacific Forum on Science Learning and Teaching, 11(1), 1-20.

Salazar-Aramayo, J. L., Rodrigues-da-Silveira, R., Rodrigues-de-Almeida, M., \& De Castro-Dantas, T. N. (2013). A conceptual model for project management of exploration and production in the oil and gas industry: The case of a Brazilian company. International Journal of Project Management, 31(4), 589-601. https://doi.org/10.1016/j.ijproman.2012.0
9.016

Saputra, H., Suhandi, A., \& Setiawan, A. (2019). Profile of inquiry skills pre-service physics teacher in Aceh. Journal of Physics: Conference Series, 1157(3). https://doi.org/10.1088/17426596/1157/3/032046

Soland, J., Hamilton, L. S., \& Stecher, B. M. (2013). Measuring 21st century competencies: Guidance for educators. Asia Society Global Cities Education Network Report, (November), 68. Retrieved from http://asiasociety.org/files/gcenmeasuring21cskills.pdf

Yadav, M. K. (2014). Clarifying the misconception about the principle of floatation. Physics Education, 49(5), 523$525 . \quad$ https://doi.org/10.1088/00319120/49/5/523

Yusal, Y., Suhandi, A., Setiawan, W., \& Kaniawati, I. (2021). Peningkatan Level Pemahaman Konsep Teori Kinetik Gas Mahasiswa Calon Guru Fisika Melalui Metode Demontrasi Interaktif dengan Bantuan Ragam Media Visual. Jurnal Inovasi Pendidikan Fisika Dan Riset IImiah, 5(1), 27-32. 